Prima: Jurnal Pendidikan Matematika

Vol. 6, No. 1, January 2022, pp. 10-19

P-ISSN: 2579-9827, E-ISSN: 2580-2216

Web: http://jurnal.umt.ac.id/index.php/prima

\title{
ANALYSIS OF STUDENTS' CREATIVE THINKING SKILLS IN LINEAR ALGEBRA COURSES DURING THE COVID-19 PANDEMIC
}

\author{
Hairul Saleh ${ }^{1}$, Dian Nopitasari ${ }^{2}$, Ahmad Fadillah ${ }^{3}$, Westi Bilda ${ }^{4}$ \\ 1,2,3,4 Universitas Muhammadiyah Tangerang, Jl. Perintis Kemerdekaan 1/33, Indonesia \\ e-mail: diannopitasari@umt.ac.id
}

\begin{abstract}
The purpose of this study is to analyze students' creative thinking skills in linear algebra courses in the Covid-19 period. This research was conducted in students of the third semester of the academic year 2021/2022 using 28 respondents. Data collection is done using a creative thinking questionnaire of 30 statement items that have been compiled according to indicators of creative thinking ability. The scale used in this study is the Likert scale. Data analysis to find out the ability to students' creative thinking skills used narrative analysis techniques with ideal criteria, namely ideal mean and ideal deviation standards. Based on data analysis obtained as a result of using indicators: fluency (72.50), elaboration (78.00), Flexibility (72.00), originality (70.00). So it can be concluded that the creative thinking ability of students in linear algebra courses is in a moderate category with an average score of 73.13 .
\end{abstract}

Keywords: Covid-19, creative thinking, linear Algebra

\begin{abstract}
Abstrak
Tujuan dari penelitian ini ialah untuk menganalisis kemampuan berikir kreatif mahasiswa pada matakuliah aljabar linier dimasa Covid-19. Penelitian ini dilakukan di mahasiswa semester tiga tahun akademik 2021/2022 menggunakan 28 resoponden. Pengambilan data dilakukan dengan menggunakan angket berpikir kreatif sebanyak 30 item pernyataan yang sudah disusun sesuai indikator-indikator kemampuan berpikir kreatif. Skala yang dipergunakan pada penelitian ini ialah skala Likert. Analisis data untuk mengetahui kemampuan berpikir kreatif mahasiswa dipergunakan teknik analisis naratif dengan kriteria ideal yaitu mean ideal serta standar deviasi ideal. berdasarkan analisis data diperoleh akibat menggunakan indikator: fluency $(72,50)$, elaboration $(78,00)$, Flexibility $(72,00)$, originality $(70,00)$. sehingga dapat disimpulkan bahwa kemampuan berpikir kreatif mahasiswa pada mata kuliah aljabar linear berada pada kategori sedang dengan rata-rata skor 73.13.
\end{abstract}

Kata kunci: aljabar linear, berpikir kreatif, Covid-19,

\section{INTRODUCTION}

The Covid-19 pandemic, which has hit the world, one of which is Indonesia, has a real impact on various areas, including economic, social, tourism and education. The implementation of education in Indonesia during the Covid-19 pandemic has undergone several significant changes. The health crisis caused by the Covid-19 epidemic has led to online education. Online tsunami learning happened almost worldwide during the Covid-19 pandemic (Goldschmidt, 2020). Teachers and educators, as an important element of education, are needed for the unusually large transition from traditional full-time education to online or distance learning (Bao, 2020; Basilaia \& Kvavadze, 2020). The presence of the Covid-19 pandemic is forcing us to move faster in terms of innovative learning, especially technology-based learning. Mathematics also has strategic values in developing ways of 
thinking that are logical, critical, creative and innovative, as well as applications to a variety of issues related to students' daily lives and other knowledge (Fadillah et al., 2020). Covid-19 is disrupting the traditional learning process. Then a solution is needed to solve the problem. Online learning is an alternative that can solve the problem (Sadikin \& Hamidah, 2020).

Online learning effectively to carry out learning even though educators and learners are in different places (Verawardina, 2020). There are many facilities and applications available for teachers and trainers to carry out teaching and learning activities (online), including Google Meet, Zoom, Google Classroom, Youtube, television and social media Whatsapp. Firman \& Rahayu (2020) online Learning in the Midst of the Covid-19 Pandemic indicates that: 1) students have all the basic skills needed to attend online classes; 2) online learning has flexibility in its implementation and is able to stimulate the emergence of self-confidence and motivation for active learning; and 3) distance learning promotes the emergence of social distance behavior and reduces the incidence of students who are believed to allow the potential spread of Covid-19 on campus. Online learning requires teachers to evaluate effectiveness and adapt it to educational needs. It is important to do so to address aspects of learning such as the process of knowledge, morality, skills, intellect and aesthetics (Dai \& Lin, 2020; Zhu \& Liu, 2020). Digital learning can be a positive response to the COVID-19 quarantine period (Mulenga \& Marbán, 2020). As changes in online learning indirectly affect learner attractiveness (Dewi, 2020).

Today, they are under increasing pressure to harness the potential of technology to close the learning gap (Perienen, 2020). But in fact on the ground, distance learning systems (online) do not rule out the possibility of some obstacles and obstacles in the course of the learning process such as: 1) not all learners have smartphones to do online learning, 2) some areas far from the city center are severely disturbed by unstable internet networks, making it very difficult to follow online learning simultaneously, 3) Not all learners can learn as effectively as in school due to several factors such as not concentration, lack of understanding of the material and lack of parental cooperation in monitoring each child to learn at home. so that some learners who do not get maximum learning results. This is in accordance with Setyosari's opinion (Chita et al., 2020) Which states that learning done through the network (online) has many potentials including the meaning of learning, ease of access, and improvement of learning outcomes. However, it does not rule out the possibility of various 
obstacles experienced by students such as bad signals, facilities such as inadequate mobile phone or laptop communication tools, the number of internet packages that are used up, conditions at home that are very uncomfortable, and so on. So that in the midst of the Covid19 pandemic, the hope is that every student continues to learn, has a high learning spirit, and is able to optimize his potential. One of the skills students have is the ability to think creatively while learning online.

Success in the learning process is not only involved in the cognitive realm is also influenced by affective conditions owned by students. There are at least some characteristics that describe the affective condition of students, among others: attitudes or behaviors, interests or interests, self-concepts, values, and morals or ethics. One of the affective characteristics that contribute to students' success in learning is the ability to think creatively. Sugilar (2013) Students' creative thinking skills cannot develop properly if in the learning process teachers do not involve students actively in the formation of concepts, learning methods used in schools are still conventional, namely teacher-centered learning. Learning can inhibit the development of creativity and student activities such as in terms of communicating ideas and ideas. So that this situation is no longer in accordance with the targets and objectives of mathematical learning. Learning objectives are achieved when the planning and methods used can influence the learners' potential and abilities, and success is achieved when the learners participate in the thought process. Andiyana et al., (2018) creative thinking skills are the ability of students to draw conclusions from a mathematical problem through non-routine steps. By thinking creatively learners are able to do various things to solve mathematical concepts with different points of view. Dilla et al., (2018) the ability to think, critical thinking and creative thinking are important ability for students to have so that students can solve problems faced in an ever-changing world. Therefore, developing thinking skills, including critical thinking and creative thinking, is important and should be taught to students from elementary to high school. Wulandari \& Mashuri, (2014) A teacher must be able to develop the subject matter and develop problems so that the student's mathematical creative thinking skills are increasingly honed and directed.

Some previous research related to the ability to think creatively, among others: Sari et al., (2013) The results showed that creative thinking skills in Basic Technology Education learning were divided into three categories, namely high, medium and low. The dominant 
creative thinking ability of students is in the moderate category. The highest percentage of characteristics of creative thinking is originality and the lowest is elaboration. As for student achievement, there was an increase in student achievement after ptd learning was applied with a normalized gain of 0.43 with a moderate category; Febrianti et al., (2016) The results showed that the creative thinking of learners consists of 5 indicators, namely flu ent skills with excellent criteria (83.76\%); flexible skills with excellent criteria (89.1\%); original skills with good criteria (79.9\%); skills detailed with good criteria (79.9\%); as well as excellent evaluating skills (86.30\%). While the results of the interview by utilizing the environment with good criteria (79.25\%); Hidayat \& Widjajanti (2018) The results showed that the category of creative thinking skills in CTL classes with open ended is in the high category, in CTL classes are in the medium category, for the learning interest category, students in both classes are in the high category, the category aspect of creative thinking ability for both classes has the highest percentage on the aspect of smoothness, students' learning interest for both classes increases significantly, And the CTL approach uses open ended questions better than the CTL approach in terms of students' creative thinking skills, while the CTL approach using open ended questions is no better than the CTL approach in terms of students' learning interests. Based on the above description and from previously conducted research, The aim of this study was to gain an overview of students creative thinking skills in linear algebra course learning during the Covid-19 pandemic.

\section{METHODS}

This research was conducted to find out and describe the creative thinking skills of students in linear algebra courses. This type of research is qualitative research. Qualitative research is a research method for determining meaning (Creswell \& Creswell, 2018). The approach used in this study places more emphasis on descriptive studies for data analysis. The subject in this study was a 3rd semester student majoring in mathematics education at the University of Muhammadiyah Tangerang with a total of 28 respondents. Researchers are the main tool of the study, as Sugiyono (2016) proves Researchers are the main tool. The position of the researcher as the main instrument is as a planner, implementer of data collection, analysis, interpreter of data and in the end the researcher becomes a whistleblower of research results (Moleong, 2019). 
In addition to researchers as a primary instrument, there are instruments in the form of questions structured on the basis of creative thinking skills indicators and field records. The awarding of questionnaires was done through google form due to the Covid-19 pandemic outbreak and the scale used in this study is the Likert scale. Sugiyono, (2015) The likert scale is used to measure the attitudes, opinions and perceptions of a person or group of people about social phenomena. The results of the score of creative thinking skills are obtained based on the packaging criteria adapted from Sugiyono (2016).

Table 1. Classification of Questionnaire Score Results

\begin{tabular}{cc}
\hline Score & Category \\
\hline $75-100$ & High \\
$50-74,99$ & Medium \\
$25-49,99$ & Less \\
$0-24,99$ & Low \\
\hline
\end{tabular}

Indicators of creative thinking skills in this study are adapted from research (Firdaus et al., (2018); Heryanti (2020); Wahyuningrum et al., (2019)) Creative thinking is a part of creativity in the creative process that has its own criteria for students' creative behavior that describe their abilities.

Table 2. Indicators of Creative Thinking Skills

\begin{tabular}{cl}
\hline Indicator & \multicolumn{1}{c}{ Behavior or Attitude } \\
\hline Fluency & $\begin{array}{l}\text { The student's ability to answer problems appropriately so as } \\
\text { to generate many ideas, ideas, give questions smoothly, advice } \\
\text { to do things, always think of more than one answer } \\
\text { The ability to expand answers, add or detail ideas so that they } \\
\text { become more interesting } \\
\text { Flexibility }\end{array}$ \\
$\begin{array}{l}\text { Students' ability to answer in different ways, generating ideas, } \\
\text { answers, or questions that vary } \\
\text { Originality }\end{array}$ & $\begin{array}{l}\text { The student's ability to answer using his own language or } \\
\text { ideas, able to make different combinations from existing ones }\end{array}$ \\
\hline
\end{tabular}

\section{RESULTS AND DISCUSSION}

In this study, educational and online educational activities were conducted, students were summarized using educational materials and films that were discussed in accordance with the materials. In addition, students also receive space for discussion and ability to find materials from various sources of online books and resources such as emodul, which are widely available. In this discussion, students will receive the possibility of providing existing advice or argument related to discussions or apply materials or problems that do not understand. If students with mistakes in understanding the concept, students or other 
teachers can improve students' understanding directly by providing proper interpretations or interpretations. Discussion activities are expected to affect the best creative thinking skills. The next step is to provide creative thinking skills for students.

This research paper discusses and describes students' creative thinking skills in linear algebra classes. The questionnaire presented is a questionnaire on a scale comparable with a maximum of 30 negative and positive statements. The results of creative thinking skills can be seen in the following table.

Table 3. Results of Analysis of Creative Thinking Skills

\begin{tabular}{|c|c|c|c|}
\hline Indicator & Behavior or Attitude & Score & Criteria \\
\hline Fluency & $\begin{array}{l}\text { The student's ability to answer problems appropriately so } \\
\text { as to generate many ideas, ideas, give questions smoothly, } \\
\text { advice to do things, always think of more than one answer }\end{array}$ & 72,50 & Medium \\
\hline Elaboration & $\begin{array}{l}\text { The ability to expand answers, add or detail ideas so that } \\
\text { they become more interesting }\end{array}$ & 78,00 & High \\
\hline Flexibility & $\begin{array}{l}\text { Students' ability to answer in different ways, generating } \\
\text { ideas, answers, or questions that vary }\end{array}$ & 72,00 & Medium \\
\hline \multirow[t]{2}{*}{ Originality } & $\begin{array}{l}\text { The student's ability to answer using his own language or } \\
\text { ideas, able to make different combinations from existing } \\
\text { ones }\end{array}$ & 70,00 & Medium \\
\hline & Average score & 73,13 & Medium \\
\hline
\end{tabular}

Based on the table above, the average creative thinking ability score was obtained at

73.13 with a moderate category. The highest score of 78.00 is obtained for elaboration indicators with behavior or attitude The ability to expand answers, add or detail ideas so that they become more interesting. The lowest score is 70.00 for the originality indicator with behavior or attitude The student's ability to answer using his own language or ideas, is able to make combinations that are different from existing ones. Of the 28 respondents, researchers only selected 4 respondents randomly to analyze their thinking skills, this is in accordance with their opinion Fadillah et al., (2021) which states that 4 respondents because it is considered to represent various respondents.

A1 respondents are able to provide more than one alternative answer that is right, able to provide answers in different ways and is of true value, has not been able to provide new answers, is able to provide diverse answers correctly, although there are differences in answers but not too significant so that the answer can be said to be the same, has not been able to provide answers in a different way of settlement. Although there are various answers but the answer has the same answer pattern, has not been able to provide new answers in accordance with his own thinking. Able to provide answers with more than one alternative 
answer correctly (fluency). Subject A1 is able to provide new answers in different and correct ways (flexibility). This is evidenced by the answers of subjects who appear different or do not follow the same pattern.

A2 respondents are only able to provide one laternative answer that is of true value, has not been able to provide answers by different ways of solving, has not been able to provide new answers, has not been able to provide diverse answers correctly, has not been able to provide answers in a different way of solving, has not been able to provide new answers in accordance with their own thinking, does not understand the given problem so it is not able to make a problem that can be solved. Not being able to provide answers with more than one alternative answer correctly (fluency). A2 respondents were only able to provide one alternative answer to all problems given both on the first test and on the second test. A2' respondents were unable to provide new answers in a different and correct way (flexibility).

A3 respondents are able to provide more than one alternative answer that is right, able to provide answers in different ways of solving, has not been able to provide answers with his own thinking, able to create problems that can be solved with diverse answers, able to provide answers with different solutions correctly, has not been able to provide new answers in his own way of thinking. A3 respondents were able to provide answers with more than one alternative answer correctly (fluency). A3 respondents are able to provide new answers in different and correct ways (flexibility). This is evidenced by the answers of subjects who appear different or do not follow the same pattern.

A4 respondents have not been able to provide more than one alternative answer correctly, have not been able to provide answers in a different way of solving smoothly, have not been able to provide new answers in their own way of thinking, able to create a problem that can be solved even though it has not been able to provide more than one alternative answer that is right, has not been able to provide new answers in its own way of thinking. A4 respondents were unable to provide answers with more than one alternative to the correct answer smoothly (fluency). A4 respondents only provided one alternative answer to all problems or gave no answers at all. A2 respondents were unable to provide new answers in a different and correct way (flexibility). 


\section{CONCLUSION}

Based on the results of this research analysis, it can be concluded that one of the subjects who are able to complete high mathematics meets two indicators of mathematical creative thinking ability that is able to solve problems with more than one alternative answer (fluency) and able to solve Problems with a variety of different and correct ways (flexibility). The subject is in the creative category. One of the other subjects was in the uncreative category. One of the subjects meets two indicators of mathematical creative thinking ability in moderate mathematical ability, namely being able to solve more than one correct answer (fluency) and being able to solve the problem in a variety of different and correct ways (flexibility), so that the subject is in the creative category. One of the other subjects was in the uncreative category) At low mathematical ability both subjects did not meet a single indicator of mathematical creative thinking ability so the subject was in the uncreative category.

\section{ACKNOWLEDGMENTS}

This research is inseparable from the help and support of many parties to thanks the Diktilitbang Pimpinan Pusat Muhammadiyah through RisetMu Grant who has funded this research. Identify those who have contributed to the research, especially the sponsors who fund your research. List the people you helped with your studies: Advisors, Financial Supporters, or other supporters, ie. Repair readers, scribes, and vendors who may have provided material.

\section{REFERENCES}

Andiyana, M. A., Maya, R., \& Hidayat, W. (2018). ANALISIS KEMAMPUAN BERPIKIR KREATIF MATEMATIS SISWA SMP PADA MATERI BANGUN RUANG. JPMI (Jurnal Pembelajaran Matematika Inovatif), 1(3), 239-248. https://doi.org/10.22460/jpmi.v1i3.p239-248

Bao, W. (2020). COVID -19 and online teaching in higher education: A case study of Peking University . Human Behavior and Emerging Technologies. https://doi.org/10.1002/hbe2.191

Cheema, J. R. (2013). Does it matter how you measure it? the case of self-efficacy in mathematics. Issues in Educational Research. 
Chita, A., Harahap, P., \& Harahap, S. R. (2020). Covid 19: Self Regulated Learning Mahasiswa. Al-Irsyad: Jurnal Pendidikan Dan Konseling.

Creswell, J. W., \& Creswell, J. D. (2018). Research and Design Qualitative, Quantitative and Mixed Methods Approaches. In Thousand Oaks California.

Dai, D., \& Lin, G. (2020). Online Home Study Plan for Postponed 2020 Spring Semester during the COVID-19 Epidemic: A Case Study of Tangquan Middle School in Nanjing, Jiangsu Province, China. SSRN Electronic Journal. https://doi.org/10.2139/ssrn.3555539

Dewi, W. A. F. (2020). Dampak COVID-19 terhadap Implementasi PembelajaDewi, W. A. F. (2020). Dampak COVID-19 terhadap Implementasi Pembelajaran Daring di Sekolah Dasar. EDUKATIF : JURNAL ILMU PENDIDIKAN. https://doi.org/10.31004/edukatif.v2i1.89ran Daring di Sekolah Dasar. EDUKATIF: JURNAL ILMU PENDIDIKAN.

Dilla, S. C., Hidayat, W., \& Rohaeti, E. E. (2018). Faktor Gender dan Resiliensi dalam Pencapaian Kemampuan Berpikir Kreatif Matematis Siswa SMA. Journal of Medives: Journal of Mathematics Education IKIP Veteran Semarang, 2(1), 129-136. https://doi.org/10.31331/medives.v2i1.553

Fadillah, A., Nopitasari, D., \& Pradja, B. P. (2020). Blended Learning Model During the Covid19 Pandemic: Analysis of Student's' Mathematical Disposition. JTAM (Jurnal Teori Dan Aplikasi Matematika), 4(2), 173-181. https://doi.org/10.31764/jtam.v4i2.2582

Fadillah, A., Sukmawati, R., \& Rahardjo, S. (2021). AKSIOMA: Jurnal Program Studi Pendidikan Matematika 1206/ ANALYSIS OF STUDENT DIGITAL LITERACY IN LINEAR ALGEBRA COURSES DURING THE COVID-19 PANDEMIC. 10(2), 1206-1212. https://doi.org/10.24127/ajpm.v10i2.3704

Febrianti, Y., Djahir, Y., \& Fatimah, S. (2016). Analisis Kemampuan Berpikir Kreatif Peserta Didik dengan Memanfaatkan Lingkungan pada Mata Pelajaran Ekonomi di SMA Negeri 6 Palembang. Jurnal Profit, 3(1), 121-127. http;//ejournal.unsri.ac.id/index.php/jp/issue/view/591

Firdaus, H. M., Widodo, A., \& Rochintaniawati, D. (2018). Analisis Kemampuan Berpikir Kreatif dan Proses Pengembangan Kemampuan Berpikir Kreatif Siswa SMP pada Pembelajaran Biologi. Assimilation: Indonesian Journal of Biology Education, 1(1), 21-28. https://doi.org/10.17509/aijbe.v1i1.11452 
Firman, F., \& Rahayu, S. (2020). Pembelajaran Online di Tengah Pandemi Covid-19. Indonesian Journal of Educational Science (IJES). https://doi.org/10.31605/ijes.v2i2.659

Goldschmidt, K. (2020). The COVID-19 Pandemic: Technology use to Support the Wellbeing of Children. Journal of Pediatric Nursing, 53, 88-90. https://doi.org/10.1016/j.pedn.2020.04.013

Hidayat, P. W., \& Widjajanti, D. B. (2018). Analisis kemampuan berpikir kreatif dan minat belajar siswa dalam mengerjakan soal open ended dengan pendekatan CTL. Pythagoras: Jurnal Pendidikan Matematika, 13(1), 63-75. https://doi.org/10.21831/pg.v13i1.21167

Moleong, L. J. (2019). Metodologi Penelitian Kualitatif (Edisi Revisi). PT. Remaja Rosda Karya. https://doi.org/10.1016/j.carbpol.2013.02.055

Mulenga, E. M., \& Marbán, J. M. (2020). Is COVID-19 the Gateway for Digital Learning in Mathematics Education? Contemporary Educational Technology, 12(2), 1-11. https://doi.org/10.30935/cedtech/7949

Perienen, A. (2020). Frameworks for ICT Integration in Mathematics Education - A Teacher's Perspective. Eurasia Journal of Mathematics, Science and Technology Education. https://doi.org/10.29333/ejmste/7803

Sadikin, A., \& Hamidah, A. (2020). Pembelajaran Daring di Tengah Wabah Covid-19. Biosilico. https://doi.org/10.22437/bio.v6i2.9759

Sari, I. M., Sumiati, E., \& Siahaan, P. (2013). ANALISIS KEMAMPUAN BERPIKIR KREATIF SISWA SMP DALAM PEMBELAJARAN PENDIDIKAN TEKNOLOGI DASAR (PTD). Jurnal Pengajaran Matematika Dan Ilmu Pengetahuan Alam, 18(1), 60-68. https://doi.org/10.18269/jpmipa.v18i1.258

Sugiyono. (2015). Metode Penelitian. Metode Penelitian. 